\title{
POSSIBILITIES FOR THE DEVELOPMENT OF SUSTAINABLE URBAN ECOTOURISM IN PROTECTED AREA "VELIKO RATNO OSTRVO"
}

\author{
Daniela Cvetković ${ }^{1 *}$ \\ Tanja Kukobat ${ }^{2}$ \\ ${ }^{1}$ Singidunum University, \\ Belgrade, Serbia \\ ${ }^{2}$ Environmental Affairs Officer at the \\ Municipality of Zemun, \\ Belgrade, Serbia
}

\begin{abstract}
:
The principles of sustainable tourism can be best perceived on the example of the ecotourism, i.e. a form of tourism that promotes the protection of natural areas through environmentally responsible behavior of tourists and the tourism industry along with the active participation of the local community which contributes to the economic development of eco-destination. Ecotourism is often associated with the stay of tourists in protected natural areas, located in remote, rural areas. Nowadays, the role of protected areas located close to major urban centers gains in importance in the development of urban ecotourism. The Landscape of Outstanding Features (LOF) «Veliko ratno ostrvo» is one of the protected areas in the capital of Serbia, Belgrade. It stands out for its specific position at the confluence of the Sava and the Danube, preserved wetlands and forest ecosystems, great species diversity, especially in ornithofauna, history and exceptional potential for ecotourism development. The aim of this paper is to present a detailed analysis of the ecotourism potential of the protected area located in the center of the metropolis, and to indicate the types of ecotourism activities that can be successfully implemented without compromising the natural values of the «Veliko ratno ostrvo».
\end{abstract}

\section{Keywords:}

ecotourism potential, types of ecotourism, urban eco-destination, urban protected area, Veliko ratno ostrvo (VRO).

\section{INTRODUCTION}

The second half of the $20^{\text {th }}$ century was characterized by the intensive and unrestrained tourism development, which has consequently resulted in increasing environmental degradation and excessive exploitation of natural resources. This led to a gradual acceptance of the new tourism development concept, so-called sustainable tourism, which is aligned with the capacity of the environment and rational use of natural resources on which it is based. Sustainable tourism should ensure long-term economic growth while respecting the socio-cultural authenticities of tourist destinations and preserving their natural and cultural heritage (UNEP and UNWTO, 2005).

Unlike other economic activities, the development of tourism in a given area depends to a great extent on the quality of the environment and the degree of preservation and attractiveness of its natural and
Correspondence:

Daniela Cvetković

e-mail:

danielacvetkovic@singidunum.ac.rs 
cultural values (Novaković - Kostić \& Trumbulović, 2016). In this regard, the perspective of sustainable tourism development can be observed through the function of nature protection and landscapes with preserved nature viewed as increasingly desirable tourist destinations.

The principles of sustainable tourism can be best perceived on the example of the ecotourism, i.e. a form of tourism that promotes the protection of natural areas through environmentally responsible behavior of tourists and the tourism industry along with the active participation of the local community which contributes to the economic development of eco-destination.

Ecotourism is often associated with nature-based travel of tourists to protected areas where the main components of the tourist offer are their natural characteristics such as climate, relief, geomorphological and hydrological phenomena, preserved ecosystems, wetlands, landscapes, diverse flora and fauna, etc.

In addition to these natural features, a significant element of the tourist offer of certain ecotourism destinations are anthropogenic attractions (cultural and historical monuments, archeological sites, medieval fortifications, monasteries and churches, cultural landscapes) as well as intangible cultural heritage (customs, traditions, folklore, local crafts, music) based on the socio-cultural identity of the local community.

Based on various criteria of the International Union for Conservation of Nature (IUCN), protected natural areas are classified into certain categories (IUCN, 1994, p.7). In almost all of the categories of protected areas, it is possible to develop different forms of sustainable tourism following the prescribed regimes of protection (Eagles et. al, 2002). Some forms of tourism and recreation appear as the primary management goal in the categories of protected areas such as national parks, natural monuments and protected landscape or seascape (IUCN, 1994, p.8).

While protected areas represent a resource basis for the development of ecotourism (Cvetković \& Đorđević, 2011), ecotourism is also a significant tool that, through economic instruments, could provide a source of funding for nature protection and generate income for local communities (Stojanović, 2011).

Through various educational and research activities as well as various forms of outdoor exercise in nature, ecotourism enables a visitor from urbanized, industrial areas to spend some time in the natural environment, develop eco-friendly behavior and environmental awareness and become a new factor of promoting its preservation, protection and sustainability.

When it comes to ecotourism development in protected areas, it is usually referred to the areas located in remote and less densely populated, rural areas.

Nowadays, when considering world population growth that is followed by urbanization, industrialization, land-use change, space modification, and often destruction of natural ecosystems and landscapes, a role of protected areas located close to major urban centers is substantial for improving the quality of life in an urban environment but also for the development of urban ecotourism.

Urban ecotourism opens new perspectives in the field of tourism and compared to traditional ecotourism offers certain advantages in terms of financial viability, since it may generate more revenue by attracting a large number of potential tourists and providing specific ecotourism experiences in urban settings (Dodds \& Joppe, 2001; Higham \& Luck, 2002; Page \& Hall, 2003).

This paper aims to present a detailed analysis of the ecotourism potential of the protected area located in the center of the metropolis and to indicate the types of ecotourism activities that can be successfully implemented without compromising the natural values of this protected area.

For the purpose of this research, one of the protected areas in the capital of Serbia, Belgrade has been selected as a case study. The Landscape of Outstanding Features (LOF) "Veliko ratno ostrvo", stands out for its specific position at the confluence of the Sava and the Danube, preserved wetlands and forest ecosystems, great species diversity, especially in ornithofauna, history and exceptional potential for ecotourism development.

The main objective of this research is to explore the possibilities of urban ecotourism development in the "Veliko ratno ostrvo", propose an innovative model of sustainable ecotourism development through a rich ecotourist offer providing a range of visitor experiences as well as to point out that only with adequate valorisation of its potential "Veliko ratno ostrvo" can become a significant urban eco-destination of Belgrade. 


\section{LITERATURE REVIEW}

The essence of the concept of the sustainable development has been thoroughly elaborated in the report entitled "Our common future" published by the World Commission on Environment and Development, according to which sustainable development implies such development of a society that allows the needs of both current and future generations to be fulfilled, while protecting and preserving the environment and natural resources (WCED, 1987).

The early 1970s were marked by increasing discussions about the negative impact of economic development on the environment, finally resulting in a general international agreement that further economic and social progress will not be possible without the adoption of a sustainable development strategy. The agreement was reached at the United Nations Conference on Environment and Development (UNCED), held in Rio de Janeiro in 1992. The largest international meeting of the UN ever held (the first Earth Summit) gathered representatives of 178 countries and it will be remembered for the adoption of the series of documents and legal instruments through which the concept of sustainable development received its full affirmation. Global Sustainable Development Action Plan for the $21^{\text {st }}$ century, called Agenda 21, was one of the most important documents adopted at the conference. Agenda 21 is a comprehensive program of actions to be undertaken at all levels (global, national and local) to address burning issues in any economic activity characterized by a strong anthropogenic impact on the environment (UNCED, 1992).

Given the fact that tourism is one of the fastest-growing economic sectors, showing a number of both positive and negative effects on the development of tourist destinations and based on the general principles of sustainability contained in Agenda 21, a special document Agenda 21 for the travel \& tourism industry, was jointly adopted by the World Tourism Organization (WTO), the World Travel and Tourism Council (WTTC) and the Earth Council (EC) in 1995 (WTTC, WTO and EC, 1995). This document represents a program of activities in the field of travel and tourism, aimed to define the operational framework of all participants in tourism sector in the direction of sustainable tourism development at the institutional level (Jegdić, 2011). As a main task of hotel companies and travel agencies, this document imposes the necessary activities in priority sectors such as waste reduction, recycling, wastewater management, energy efficiency, clean water resources management, land use planning, and management, etc. (Bošković, 2008).

Due to its specific characteristics, tourism is one of the economy sectors which can significantly contribute to the implementation of the environmental, economic and social sustainability as well as achieving sustainable development goals (CSD, 1999). In ecological sense, tourism industry depends on the natural resources but the negative effect of tourism development on natural resources and environment is less pronounced, compared to other industrial branches. From an economic point of view, tourism provides real opportunity for employment, poverty reduction, fostering regional development, long-term profitability of the tourist companies and also for generating funds to protect natural landscapes and ecosystems and preserve natural and cultural heritage sites. The social aspects of sustainability are reflected in the increasing awareness of tourists on environmental conditions of destinations and other issues concerning the impacts of their travelling on the environment at the destination, as well strengthening interaction between visitors and local (host) communities.

World Tourism organization (WTO) believes that the sustainability guiding principles and practices can be applied to all forms of tourism and different types of tourist destinations, involving mass tourism, as well as various market segments of the tourism industry (UNEP and UNWTO, 2005).

Furthermore, UNWTO (2005) has given one of the most cited and widely accepted conceptual definitions of sustainable tourism according to which sustainable tourism takes into consideration not only current environmental, economic and social tourism impacts, but also future impacts, whilst referring to the present and future needs of visitors, the industry, the environment and the local community.

Along with raising awareness of the need for a more responsible and humane attitude towards the natural environment and as a response to the growing interest of a certain group of tourists for a new type of experience and vacation in areas with preserved nature, a new, alternative form of sustainable tourism - ecotourism has emerged in the 80 s of the last century. 
The main components of ecotourism by which it differs from the wider concept of sustainable tourism, are emphasized in the most important document addressing ecotourism, the Quebec Declaration on Ecotourism adopted in 2002 at the World Ecotourism Summit in the framework of the UN International Year of Ecotourism: (1) contribution to the conservation of natural and cultural heritage; (2) involving local and indigenous communities in ecotourism development and contribution to their welfare; (3) the interpretation of natural and cultural heritage to visitors; (4) encouraging independent travelers, as well as organized tours for small size groups (UNEP and WTO, 2002).

As a sustainable version of nature-based tourism, ecotourism includes a set of principles to be followed when planning its development: (1) minimize negative impacts; (2) increase environmental and cultural awareness; (3) create positive experiences for both visitors and hosts; (4) ensure direct funding for conservation and protected area management; (5) generate profits for both local people (family business) and private industry; (6) deliver unforgettable, meaningful, quality experiences to visitors; (7) design and construct facilities and infrastructure with low impact on the environment; (8) lowest possible consumption of non-renewable resources; (9) foster respect and promote the rights and culture of the indigenous people and strengthening the partnership with them; (10) establishment of educational and training programs (Wood, UNEP \& IES, 2002; McLaughlin, 2011; Lackey et al., 2019).

Although ecotourism is small scale within niche tourism marketplace, it is considered to be one of the rapidly growing segments of the tourism industry worldwide (Wood, UNEP \& IES, 2002).

While traditional ecotourism involves travelling to relatively unaltered and uncontaminated natural areas (Ceballos-Lascurain, 1987), modified areas that offer some degree of naturalness in urban settings can be acceptable likewise as an ecotourist destination (Higham \& Lück, 2002).

The concept of urban ecotourism was first defined by Blackstone Corporation in 1996, as „one of the sustainable ways of travelling in urban areas" (Wu et al., 2010). During the first International Urban Ecotourism Conference, held in 2004, in Canada, concept of urban ecotourism has been revised and recognized as an opportunity to conserve and restore natural and cultural heritage, support social diversity and maximize economic benefits to local community through employment creation, educate visitors and residents on environmental matters and enhance the quality of life in urban environments (Urban Ecotourism Declaration, 2004).

According to some authors, there are several advantages that urban ecotourism offers compared to the traditional ecotourism, which are as follows: 1) Environmental impact - urban ecotourists do not travel long distances to tourist destinations, so they may use existing infrastructure and public transport; 2) Restoration of natural areas - natural values can be renewed through implementation of restoration projects (habitat creation for endangered and migratory species, afforestation, dredging of muddy sections of watercourse etc.) while providing exclusive ecotourism experiences; 3) Interpretation and education - promotion of nature protection and sustainability to a wider public in urban settings in order to influence their environmental behaviour; 4) Financial viability - this type of ecotourism attracts a wider scale of social categories and a larger number of visitors during the year and is usually less affected by seasonality than other types of tourism, which has an impact on employment and revenues; 5) Advantages in the field of destination marketing - city promotion is enriched by ecotourism offer (Dodds \& Joppe, 2001; Higham \& Luck, 2002; Page \& Hall, 2003; Okech, 2009; Freslon, 2010).

\section{DISCUSSION}

\section{Study area: The Landscape of Outstanding Features (LOF) "Veliko ratno ostrvo"}

The "Veliko ratno ostrvo" is a river island created as a unique geomorphological formation, at the confluence of the Sava and the Danube, during the $16^{\text {th }}$ century. South of the Great War Island, in the Danube armlet (Dunavac), there is the "Malo ratno ostrvo", about $700 \mathrm{~m}$ long. With a total area of 211.38 ha, the island territorially belongs to the municipality of Zemun, and administratively to the city of Belgrade.

Situated between the Belgrade fortress Kalemegdan in the east and the Medieval fortress of Zemun, Gardoš tower in the west, the island had a key strategic position in military operations during the Ottoman and AustroHungarian era, which is the reason why it is called "Great War Island". 
The island is mostly covered with the complex of the wetland forest ecosystems of white poplar (Populus alba) and black poplar (Populus nigra) and the communities of alluvial forests of the white willow (Salix alba) (Amidžić et al., 2007). Abundant vegetation consists of aquatic and marsh communities and is directly dependent on the flooding and groundwater regime.

Well-developed vegetation and the presence of wetlands and open water surfaces provide food and habitat for breeding and nesting of a substantial number of internationally important birds, among which is a protected species - the white-tailed eagle, the largest eagle in Europe.

During springtime flooding, numerous fish species enter the permanent or ephemeral ponds for spawning needs, so the Island is officially proclamed as one of the natural fish spawning area within the fishery area "Danube III".

In 2005 "Veliko ratno ostrvo" was placed under the protection, by the Decision of the Assembly of the City of Belgrade as a landscape of outstanding features, in order to preserve picturesque landscape features and undisturbed habitats of natural rarities, rare and endangered wetland birds, as well as to protect representative morphological and geological formations - river island (Decision, No. 501-362/05-XII-01). The manager of the protected area is the Public Utility Company "Zelenilo Beograd".

According to the international classification (International Union for Conservation of Nature - IUCN), the "Veliko ratno ostrvo" belongs to the IV category - Habitat/Species Management Areas. The presence of 196 bird species was recorded on the island, most of which have the status of internationally significant species, wherefore the island is on the list of Important Bird Area (IBA). Veliko ratno ostrvo is also a part of Emerald network (European Ecological Network of Protected Natural Areas).

\section{Protection regimes at protected area "Veliko ratno ostrvo"}

In accordance with the Law on nature protection ("Official Gazette of RS", Nos. 36/2009, 88/2010 and 91/2010 - corr., 14/2016 and 95/2018 - other law), the protected natural area "Veliko ratno ostrvo" is categorized as a significant natural area, within which three zones with different protection regimes have been determined: regime zones of I, II and III degree of protection (see Fig. 1).

A three-level protection regime has been identified in Study on protection (INPS, 2002) as follows:

1. Nature protection zone (first protection regime) - with the character of a special nature reserve, includes Malo ratno ostrvo, shore-zone of "Veliko ratno ostrvo" (towards Danube and Sava foreland), forest complex, wetlands within Veliko ratno ostrvo, water surfaces surrounding Malo ratno ostrvo.

2. Recreation zone (second-degree protection regime) - comprises the inner parts of "Veliko ratno ostrvo", the former farmland still used in that status in present, grasslands of coastal area towards the Danube forland, which are now partially occupied by illegal objects mostly in a very dilapidated condition and the former grasslands threatened by invasive species, as well as location of the public pier with controlled public traffic route and protection zone with a width of $10 \mathrm{~m}$ connecting this site with the Lido beach. Within this protection zone, an open rustic amphitheater in nature is located, intended for the realization of educational camps and other promotional activities.

3. Tourism zone (third-degree protection regime) - involves the Lido beach with planned expansion where an organized tourist-recreational offer and new contents could be provided. Lido beach is traditionally used as a picnic area for the residents of Zemun. It is extremely visited in summer, even though is poorly infrastructurally equipped.

General measures of protection and use of the protected natural good, which prohibit certain activities and works that may have significant negative effects to representative biological, geomorphological and other natural values and fragile natural ecosystems of the protected area are applied in all three protection zones (PUC “Zelenilo Beograd”, 2010). 
Figure 1. Schematic diagram of the boundaries of the protected area "Veliko ratno ostrvo" with the prescribed protection regimes

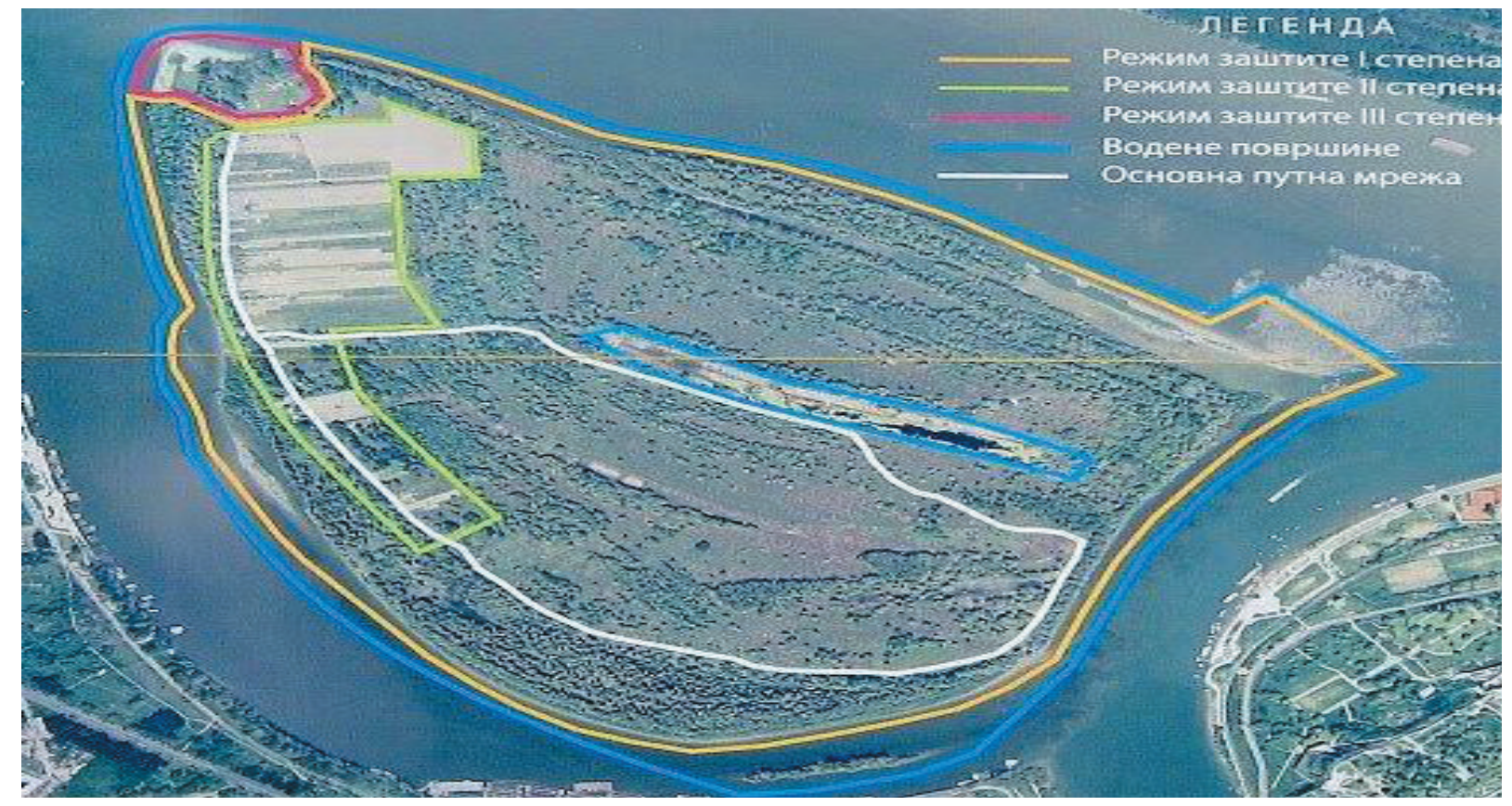

Source: https://i.imgur.com/IbiThD0.jpg

When it is talked about the ecotourism development of the Great War Island so far, it can be said that the preservation of the area has not always been in accordance with the existing legal protection (Malinić, 2016).

Analysis of permitted landscape changes and activities that could be implemented with the intention to attract eco-tourists

Natural and generated values of the LEF Veliko ratno ostrvo are the basis for the development of new resources that can be used to form a new ecotourism value. A well - planned and implemented program of sustainable educational, recreational and eco-tourism has the potential to ensure the economic development of the local community (profit, increase in the number of tourist visits, consumption, employment, etc.) and protection of natural resources.

The model of profitable ecotourism development at the LEF Veliko ratno ostrvo must provide a special tourist experience. To achieve this, many inputs have to be thoroughly considered; all the available natural and man-made resources, current and future infrastructure, possible upgrade facilities, and a deep understanding of the variable needs of the tourists. Biodiversity of the island's ornithofauna is a major attraction, but to make a beneficial tourist product, various tourist packages have to be offered; they must satisfy the needs of different groups of visitors of all ages and preferences. Tourist packages have to include a mix of new cultural projects, education, entertainment, sports and other eco-friendly contents, as well as unusual open space activities compatible with nature protection.

A stay and activities of the visitors of the natural area represent for metropolitan residents the opportunity for a rapid change of the environment, where they would be able to spend time outdoors doing different kinds of activities. This is especially convenient for urban residents who have no time to travel to distant destinations and need to be able to quickly return to their everyday schedule. For business people from Belgrade, this natural oasis is one step away from the place of residence but brings the experience and psychophysical benefit as if they were in some remote natural area. For foreign tourists visiting Belgrade, a trip to the island is a refreshing change of activities compared to the usual activities of sightseeing in the city. 
The Great War Island with its resources offers the best combination of services for visitors who want to spend time in a natural environment, and therefore can form and offer several tourist packages which include: outdoor activities of groups of visitors (families, sports teams, youth groups, groups of children, student groups, environmental and biological associations, etc.), educational camps (day camps or overnight camps), sports and recreational camps (day camps or overnight and multi-day camps), all-day active vacation in a natural environment (provides conditions for several types of recreation like jogging, cycling, kayaking, yoga outdoors, swimming, doing beach sports activities in the adventure park, combined with bird watching from the mainland, observatory or boat, visit of the wetland botanical garden etc.), active overnight vacation in the eco-village of stilt houses (a stay in a natural environment in a special atmosphere made by sleeping in a rustic setting, night sky watching, nocturnal animals watching, boat ride and sightseeing from the river, visit to the Museum of Nature and History stilt house etc.) and educational walk routs (introducing visitors to the history, geology, flora and fauna of the island) etc.

Travel packages are created based on the fact that the island abounds in many available natural resources. The most important are the unique elements and combinations of ecosystems, non-specific for a location which is at such a small distance from the metropolis and in conditions of constant pressure from people, infrastructure, traffic and various types of pollution as well as natural pressures such as periodic major floods, an influx of invasive species and climate change. A natural resource of great importance is the Danube River which protects the island from urbanisation and shapes its uniqueness, influences on formation of rich aquatic vegetation, floodable forests and meadows, wetlands and temporary and permanent water basins inside the islands, and supply shelter and food for many species, primarily birds. Different types of habitats are a prerequisite for a lush vegetation - autochthonous and allochthonous flora, especially wet and underwater meadows and wetland forests. The geographical position of the Veliko ratno ostrvo is on the way of natural migration routes along watercourses and provides extraordinary habitat conditions for the most important feature of the island - rich ornithofauna.

To complete the ecotourism offer, it is of essential importance to build facilities that can meet all the needs of tourists while respecting the requirements of space protection and integration of facilities into the natural environment. Man-made resources- facilities which could serve to meet the needs of stay and movement of tourists on the island and do not disturb landscape and natural values are the following: info desk, stilt houses for lodging or public rustic wooden gazebo/park shelters (accommodation facilities built of natural materials, with natural lighting systems, ventilation, etc., supplied with energy from alternative sources), rustic amphitheater (for lectures, gatherings, cultural events etc.), wetland botanical garden, bird watchtowers, astronomical observatory (stilt house adapted for sky watching with telescopes), interactive historical boards, Museum of Nature and History of the Great War Island (in a stilt house), online monitoring facility of natural activities on the island (watching activities at the white-tailed eagle's nest etc.), info boards, replicas of the military watchtowers (Turkish and Austro-Hungarian), recreational polygon along the trail (with wooden obstacles, wooden shelters, benches, etc.), outdoor gym, plateau for exercises (yoga, tai chi, karate and other exercises and martial arts), children and youth eco adventure parks (made of natural materials), overhead suspension bridge between military watchtower posts, pier for boats, pedal boats and kayaks (for driving around the island and along the river banks), rent-a-bike facility, landscaped beach with nearby sanitary facilities (drinking fountains, showers, toilets), catering facilities, island ranger stilt house, ambulance, pedestrian bridge (between the island and Zemun quay on the right bank of the Danube River) (see Fig. 2).

Key-value for the attraction of tourists is a combination of different kinds of eco-educational and recreational activities which could be implemented with expert guidance. These activities can include biodiversity themed route like birdwatching or presenting the flora of the wetland botanical garden and observing the night sky with a telescope. Introducing a variety of ecosystems and their biodiversity is especially attractive if conducted from the boat circling around the island and along the river banks, entering the foreland armlets on the left bank of the Danube.

Given the existence of well-maintained landscaped footpaths over $5 \mathrm{~km}$ long as well as open meadows, which fit into the requirements of spatial protection (protection regime of degree II), the Veliko ratno ostrvo enables recreational and sports activities such as cycling, jogging, plateau exercises, exercises at the recreational track, activities in the adventure parks, swimming, beach sports and kayaking and boating. 
Figure 2. Ecotourism infrastructure at the "Veliko ratno ostrvo"

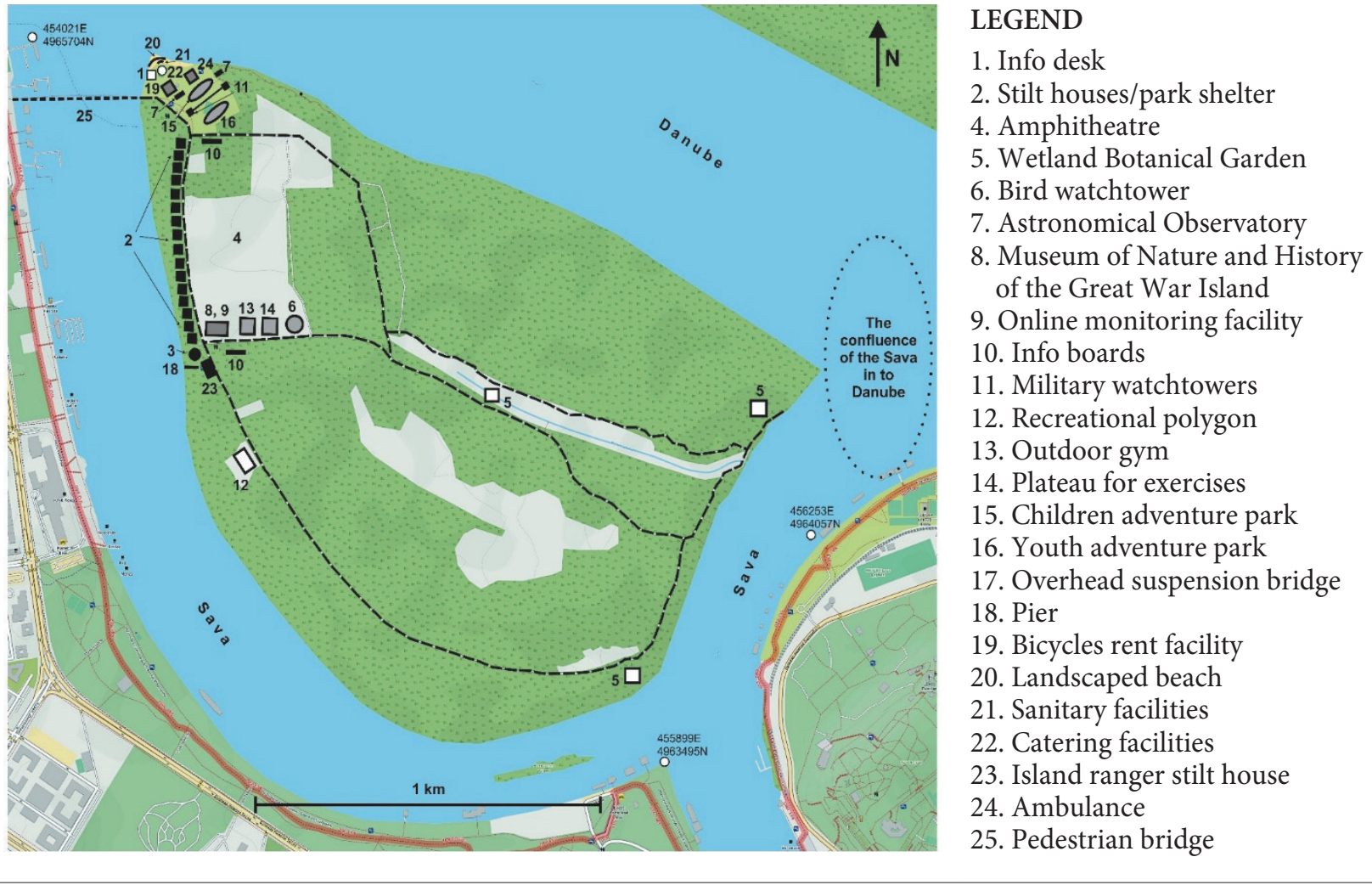

Source: Derived by Authors

\section{Excerpts from strategic documents that support the proposal for the development of eco-tourism needs}

General Regulation Plan of Building Area in Local Government - City of Belgrade (Official Gazette of the RS, No. 20, dated March 21, 2016) singles out three key recommendations for tourism development. The first of them is the Landscape of Outstanding Features "Veliko ratno ostrvo" within which is three established zones for a protected area with different protection regimes. The protection regime of the III degree is applied for Lido Beach with an extension, and allows the location of tourist-recreational facilities within the area.

The Landscape of Outstanding feature "Veliko ratno ostrvo" is listed in the Tourism Development Strategy of the Republic of Serbia for the period from 2016 to 2025 (MTTT, 2016) among the locations on the territory of Serbia attractive for bird watching and the location for gathering of a large number of species and specimens of birds. The document mentions the concept of nautical tourism and sightseeing of Belgrade from the river. The "Veliko ratno ostrvo" is also mentioned as one of the attractive locations for different types of recreation. Sports tourism and eco-tourism are, among the others, mentioned as a high-quality value for the tourist services offers.

Tourism development strategy of the Zemun Urban Municipality 2010-2016 (Gradska opština Zemun, 2010) devotes a lot of space to the "Veliko ratno ostrvo", especially to "Lido" beach and emphasizes the potential of the development of eco-tourism and sports recreational tourism on the island. The document also draws attention to the impact of the uncontrolled use of resources on the environment. However, it also underlines that Veliko ratno ostrvo is one of the important elements of tourist infrastructure and that its development is a very important tool for the improvement of the quality of life of the local population.

Local environmental action plan (LEAP) of the Zemun Urban Municipality 2018 - 2021 (Gradska opština Zemun, 2018a) describes in detail history, infrastructure and resources of the protected natural area the "Veliko ratno ostrvo", its use for sports, recreational and educational purposes and provides a conclusion that there is a perspective, due to the richness of ornithofauna, of development in the world of growing exclusive bird watching ecotourism. In order to popularize nature protection, ecological camps and ecological walking tours are traditionally organized on the "Veliko ratno ostrvo". 
The main strategic document of the Zemun Municipality concerning tourism, Tourism and Culture Development Program of the Zemun Urban Municipality 2018-2021 (Gradska opština Zemun, 2018b) identifies the "Veliko ratno ostrvo" as the resource of great importance for the development of tourism and culture, as well as for the improvement of a tourist offer.

\section{CONCLUSION}

As a representative example of a protected area which has great potential for the development of urban ecotourism, this paper cites the LEF Veliko ratno ostrvo, a unique natural landscape characterized by the presence of sensitive ecosystems, preserved wetlands and floodplain forests, with a specific geographic position at the confluence of the Sava and the Danube rivers, between Belgrade and Zemun, but also with turbulent historical heritage. Therefore, this area has a great preconditions for the development of all forms of ecotourism, primarily bird watching, followed by excursion-recreational, scientific-research, cultural-educational, nautical, excursion and bathing tourism. Although the Management plan for the Veliko ratno ostrvo emphasizes the development of sustainable ecotourism as one of the long-term goals for protection, preservation, improvement and sustainable development, the current practice shows that resources are minimally utilised and brought to use. The paper presents one of the possible models of ecotourism development on the Veliko ratno ostrvo, which is based on a diverse ecotourism offer with the support of appropriate ecotourism infrastructure. Touristic valorisation of the Veliko ratno ostrvo through the ecotourism development would enable the establishment of a financial mechanism for the preservation of its natural resources and values that are used by visitors. A precondition for the development of economic instruments for nature conservation could only be provided by active promotion of an urban eco-destination, attracting diverse range of visitors from passionate nature lovers, bird watchers, adventurers, researchers, schoolchildren and students, to other youth and adult groups and ecotourists. Ecotourism development planning must be harmonized with the prescribed protection of landscape values, conservation of biodiversity and sustainable development of the LEF Veliko ratno ostrvo. The major factors threatening the protected area such as invasive introduced species, water pollution by untreated city sewage, anthropogenic pressures on the ecosystem, illegal constructions show that the protection fails to fully establish an effective protection mechanism in practice. Consequently, in this paper we suggest that the space that has already been degraded by illegal construction should be repurposed and existing illegal objects be replaced with ecotourism infrastructure, which will ensure rational use of an area for ecotourism development. The manager should make a decision on the expansion of the second and the third protection zone by a special act which will enable establishing necessary facilities in the areas where the active protection measures and sustainable use of natural resources of the protected area have not been conducted. Setting a clear goal - realization of economic profit and conservation of natural resources, leads us to the conclusion that only sustainable use of the natural resources, supported by financial instruments could preserve nature in the modern world. In order to achieve well managed ecotourism development planning, all of stakeholders from protected area manager, professional and scientific institutions, local and city government, travel agencies and other users should be involved. Special attention must be given to the active participation of the local community, as an important factor which recognizes the natural values of the island as an inseparable part of its own identity and can contribute to the sustainable development of the Veliko ratno ostrvo. 


\section{REFERENCES}

Amidžić, L., Krasulja, S. \& Belij, S. (2007). Zaštićena područja Srbije. Beograd: Ministarstvo zaštite životne sredine i Zavod za zaštitu prirode Srbije.

Bošković, T. (2008). Održivi turizam kao savremeni koncept razvoja turizma. Škola biznisa, 4, 123-127. Retrieved September 1, 2020, from http://www.vps.ns.ac.rs/SB/2008/4.16.pdf

Ceballos-Lascurain, H. (1987). The Future of Ecotourism. Mexico Journal (January), 27: 13-14.

CSD, Commission on Sustainable Development (1999). Tourism and Sustainable Development. The Global Importance of Tourism. - Prepared by the World Travel and Tourism Organization and International Hotel and Restaurant Association. - Department of Economic and Social Affairs: Commission on Sustainable Development, Seventh Session, 19-30 April 1999, New York. Retrieved September 1, 2020, from https://sustainabledevelopment.un.org/content/documents/398wttc.pdf

Cvetković, D., Đorđević, S. (2011). Održivi turizam u zaštićenim područjima Srbije. Ecologica, 18 (2011), broj 62, 286-291. UDC:502.47.48:338.48(497.11)

Dodds, R. \& Joppe, M. (2001). Promoting urban green tourism: The development of the other map of Toronto. Journal of Vacation Marketing, 7 (3):261 - 267. DOI: 10.1177/135676670100700306.

Eagles, Paul F.J., McCool, Stephen F. \& Haynes, Christopher D.A. (2002). Sustainable Tourism in Protected Areas: Guidelines for Planning and Management. IUCN Gland, Switzerland and Cambridge, UK. xv + 183pp. Retrieved August 20, 2020, from https://portals.iucn.org/library/sites/library/files/documents/ PAG-008.pdf.

Freslon, L. d. (2010). Urban Ecotourism - The Case of Lac de Maine Leisure Park. Hold in, March 07. Retrieved, September 5, 2020, from https://ecoclub.com/articles/305-urban-ecotourism-lac-de-maine.

General Regulation Plan of Building Area in Local Government - City of Belgrade (Official Gazette of the RS, No. 20, dated March 21, 2016). Retrieved September 6, 2020, from: https://www.beoland.com/wpcontent/uploads/planovi/pgr-beograda/PGR_Tekst_SL_20-2016.pdf

Higham, J. \& Lück, M. (2002). Urban Ecotourism: A Contradiction in Terms? Journal of Ecotourism 1(1), 36-51. DOI: $10.1080 / 14724040208668111$

INPS (2002). "The Great War Island-proposal for protection of the Great and Small War Island on the river Danube in Belgrade as the area of outstanding features", Belgrade: Institute for Nature Protection of Serbia, Serbia

IUCN (1994). Guidelines for Protected Area Management Categories. CNPPA with the assistance of WCMC. IUCN, Gland, Switzerland and Cambridge, UK. x + 261pp. Retrieved August 20, 2020, from http://www. vliz.be/imisdocs/publications/ocrd/64758.pdf

Jegdić, V. (2011). Turizam i održivi razvoj. Novi Sad: Fakultet za sport i turizam.

Mader, R. (2004, June). Urban Ecotourism Declaration. Retrieved August 30, 2020, from https://www.planeta. com/urban-ecotourism-declaration/.

Malinić, V. (2016). Urban ecotourism as the concept of optimal development of the landscape of outstanding features "Veliko ratno ostrvo". Zbornik radova - Geografski fakultet Univerziteta u Beogradu, 64, 481-516. doi:10.5937/zrgfub1664481M

McLaughlin, M.J. (2011). Ecotourism Assessment: Applying the Principles of Ecotourism to Paddle-Based Recreation in St. Lawrence Islands National Park and Environs. A thesis submitted to the Graduate Program in School of Environmental Studies in conformity with the requirements for the Degree of Master of Environmental Studies. Queen's University, Kingston, Ontario, Canada, pp. 142 Retrieved September 3, 2020, from https://qspace.library.queensu.ca/bitstream/handle/1974/6852/MCLAUGHLIN_ JULIENE_M_201110_MES.pdf;jsessionid=E36413B382BF461B769B714B89623648? sequence=1

MTTT (2016). Tourism Development Strategy of the Republic of Serbia 2016-2025. Belgrade, Ministry of Trade, Tourism, and Telecommunications, Government of the Republic of Serbia. Retrieved September 6, 2020, from http://mtt.gov.rs/download/3/strategija.pdf

Novaković - Kostić, R. \& Trumbulović, Lj. (2016). Ekoturizam. Užice: Visoka poslovno tehnička škola strukovnih studija

Okech, R. N. (2009). Developing urban ecotourism in Kenyan cities: A sustainable approach. Journal of Ecology and Natural Environment Vol. 1(1), pp. 001-006, April, 2009. Retrieved September 5, 2020, from https:// academicjournals.org/journal/JENE/article-full-text-pdf/14DE9D82457

Page, S.J. \& Hall, C. M. (2003). Managing urban tourism. Harlow: Pearson Education limited, 389 pp, London. Retrieved August 25, 2020, from https://www.academia.edu/10998522/Managing_urban_tourism 
PUC "Zelenilo Beograd" (2010). Management Plan for a Landscape of Features "Veliko ratno ostrvo" 2011-2020. Belgrade: Public Utility Company “Zelenilo Beograd”, Serbia. Retrieved September 2, 2020, from https:// www.zelenilo.rs/images/dokumenta/korisni-dokumenti/Plan\%20VRO.pdf

Qwynne Lackey, Leah Joyner \& Dr. Kelly Bricker (2019). Ecotourism Outlook 2019. College of Health, The University of Utah. Retrieved September 4, 2020, from https:/ttra.com/wp-content/uploads/2019/10/ Ecotourism-Outlook-2019.pdf

Stojanović, V. (2011). Turizam i održivi razvoj. Novi Sad: Univerzitet u Novom Sadu, Prirodno-matematički fakultet, Departman za geografiju, turizam i hotelijerstvo

The Assembly of the city of Belgrade (2005). Decision on placing the natural asset "Great War Island" under protection, No. 501-362/05-XII-01, ("Official Gazette of the Belgrade”, No 7/2005), Belgrade: The Assembly of the city of Belgrade, Serbia

The Law on Nature Protection ("Official Gazette of the Republic of Serbia", Nos. 36/2009, 88/2010 and 91/2010 - corr., 14/2016 and 95/2018- other law). Retrieved September 1, 2020, from https://www.paragraf.rs/ propisi/zakon_o_zastiti_prirode.html

UNEP and WTO (2002). The Québec Declaration on Ecotourism', UNWTO Declarations, volume 12, number 2, UNWTO, Madrid. Retrieved September 2, 2020, from https://www.e-unwto.org/doi/pdf/10.18111/ unwtodeclarations.2002.12.02

UNWTO (2005). Sustainable Development of Tourism, definition. Retrieved September 1, 2020, from http:// sdt.unwto.org/content/about-us-5.

UNCED, United Nations Conference on Environment and Development (1992). Agenda 21, Rio Declaration, Forest Principles. New York: United Nations. Retrieved August, 30, 2020, from https://sustainabledevelopment.un.org/content/documents/Agenda21.pdf

UNEP and UNWTO (2005). Making Tourism More Sustainable - A Guide for Policy Makers. Retrieved August 20, 2020, from http://www.unep.fr/shared/publications/pdf/DTIx0592xPA-TourismPolicyEN.pdf

WCED, United Nations World Commission on Environment and Development (1987). Our Common Future. Retrieved August 30, 2020, from https://sustainabledevelopment.un.org/content/documents/5987ourcommon-future.pdf

Wood, M. E., United Nations Environment Programme \& International Ecotourism Society (2002). Ecotourism: Principles, practices \& policies for sustainability. Paris, France: UNEP Division of Technology, Industry and Economics. Retrieved September 3, 2020, from http://wedocs.unep.org/bitstream/handle/20.500.11822/9045/Ecotourism_Principles,PracticesandPoliciesforSustainability-2002518.pdf?sequence=2

WTTC-WTO-EC, World Travel and Tourism Council, World Tourism Organization, Earth Council (1995). Agenda 21 for the travel \& tourism industry. Towards environmental sustainable development, London and Madrid: WTTC, WTO and EC.

Wu, Y.-Y., Wang, H-L. \& Ho, Y-F. (2010). Urban ecotourism: Defining and assessing dimensions using fuzzy number construction. Tourism Management, 31 (6), 739-743. doi:10.1016/j.tourman.2009.07.014.

Gradska opština Zemun (2010). Strategija razvoj turizma GO Zemun 2010-2016. Zemun: Gradska opština Zemun, Beograd, Srbija. Retrieved, September 7, 2020, from http://www.zemun.rs/cms/sites/default/files/Strategija\%20razvoja\%20turizma_0.pdf (in Serbian)

Gradska opština Zemun (2018a). Lokalni ekološki akcioni plan (LEAP) Gradske opštine Zemun 2018 - 2021. Zemun: Gradska opština Zemun, Beograd, Srbija. Retrieved September 10, 2020, from http://zemun.rs/ wp-content/uploads/2018/05/LEAP-2018.pdf (in Serbian)

Gradska opština Zemun (2018b). Program razvoja turizma i kulture Gradske opštine Zemun za period 20182021. Zemun: Gradska opština Zemun, Beograd, Srbija. Retrieved September 8, 2020, from http://zemun. rs/wp-content/uploads/2019/01/Zemun-Program-razvoja-turizma-i-kulture-1.pdf (in Serbian) 